\title{
RECENZJA
}

\section{MACIEJ KOWALEWSKI, PROTEST MIEJSKI. PRZESTRZENIE, TOŻSAMOŚCI I PRAKTYKI NIEZADOWOLONYCH MIESZKAŃCÓW MIAST, ZAKŁAD WYDAWNICZY NOMOS, KRAKÓW 2016, SS. 371}

Publikacja Macieja Kowalewskiego, która ukazała się nakładem Zakładu Wydawniczego Nomos w roku 2016, jest pracą z zakresu nauk społecznych, dotykającą istotnego współcześnie problemu, jakim są zachowania zbiorowe obywateli miast w przestrzeni publicznej. Książka reprezentuje interdyscyplinarne podejście, w ramach którego dokonana została analiza relacji treści oraz formy protestów niezadowolonych mieszkańców miast, które mają miejsce w przestrzeni publicznej. W omawianej pracy autor uznaje miasto zarówno za podmiot, jak i kontekst badań nad zjawiskami społeczno-politycznymi, będącymi efektem współczesnych przekształceń społeczno-przestrzennych.

M. Kowalewski pełni funkcje dyrektora Instytutu Socjologii na Uniwersytecie Szczecińskim. W swoich licznych pracach koncentruje się na zagadnieniach związanych z socjologią miasta, w tym kulturą miejska, mieszkalnictwem, tożsamością obywateli miast, polityką protestu oraz ruchami społecznymi i miejskimi. Jest autorem, redaktorem, współredaktorem wielu monografii naukowych oraz autorem i współautorem licznych artykułów w znaczących czasopismach z zakresu socjologii miasta.

Publikacja składa się z trzech głównych rozdziałów, poza wprowadzeniem oraz zakończeniem. We wprowadzeniu autor określa rolę miasta i przestrzeni publicznej miasta w polityce protestu. Zwraca uwagę na symboliczną i instrumentalną funkcję przestrzeni miasta twierdząc, że „związanie lokalnych żądań i strukturalnych nierówności objawia się dzięki praktykom rozgrywającym się w fizycznej, realnej przestrzeni miejskiej. Nawet w przypadku protestów dziejących się w przestrzeni wirtualnej najczęściej mamy do czynienia z sytuacja, w której jedną z funkcji internetowego protestu jest mobilizacja do uczestnictwa w przestrzeni fizycznej" (Kowalewski, 2016, s. 23). Ponadto podkreśla również tożsamotwórczy charakter miasta jako przestrzeni, w której jest ustawicznie konstruowana i renegocjowana kolektywna tożsamość jej mieszkańców.

Cel główny książki został sformułowany dość szeroko jako ,analiza miasta jako podmiotu politycznego i przestrzeni protestu niezadowolonych obywateli" (Kowalewski, 2016, s. 30). Przy czym miasto, zgodnie $\mathrm{z}$ tym zapisem, stało się przedmiotem badań oraz analiz (które nie powinny jako takie stanowić celu pracy $\left.^{1}\right)$, a nie ich podmiotem, co autor wyjaśnił we wprowadzeniu. W dalszej części rozdziału cel ten został doprecyzowany w postaci sformułowanych celów szczegółowych i pytań badawczych. Główna hipoteza pracy zakłada, że „,tym co definiuje protest miejski, nie są oderwane od siebie formalne prawa, tożsamości oraz praktyki obywateli miast, ale powiązanie tych elementów w kontekście przestrzennym" (Kowalewski, 2016, s. 31).

W swoich rozważaniach autor odwoływał się do metodologii socjologii historycznej i do jednego z jej wariantów, jaką jest socjologia historyczna miasta (historical sociology of the city). Wykorzystanie tej metodologii miało na celu rozstrzygnięcie, czy badania odwołujące się do przeszłości miast mogą być użyteczne w badaniu zmienności zjawisk, które interesują socjologów miejskich współcześnie. Za pomocą doboru szerokiego wachlarza literatury zarówno polskiej, jak i zagranicznej z zakresu socjologii, jej nauk pokrewnych, a także geografii, szczególnie geografii społecznej miast, autor postawił sobie za cel wskazanie punktów wspólnych perspektyw socjologii historycznej i socjologii miasta. Wykazał również świadomość trudności i niedoskonałości dobranych metod oraz wykorzystywanych źródeł, uzasadniając jednak każdorazowo powody dokonanych decyzji oraz wyborów sposobów uzupełniania danych bądź udoskonalenia metodologii tam, gdzie uznał to za stosowne. 
Kolejne rozdziały poświęcone są procesowi formowania się miejskiego obywatelstwa, ruchów społecznych oraz strategiom i taktykom manifestowania niezadowolenia obywatelskiego w przestrzeni publicznej miasta. W rozdziale pierwszym autor precyzyjnie opisał proces kształtowania się obywatelstwa miejskiego, począwszy od cywilizacji starożytnych, poprzez okresy średniowieczny i nowożytny, aż do odradzającej się miejskiej demokracji czasów współczesnych. Opis ten miał jego zdaniem służyć wykazaniu „związku pomiędzy przekonaniami i tożsamościami wynikającymi z przynależności do miejskiej wspólnoty a gotowością do określonych działań politycznych." (Kowalewski, 2016, s. 38). Podkreślił elementy mające wpływ na kształtowanie się zjawiska segregacji społecznej i przestrzennej oraz takie, które wywarły wpływ na wykreowanie współczesnych nierówności i stanowiące przedmiot niezadowolenia obywateli miast. Opis zawarty $w$ rozdziale pierwszym publikacji cechuje bardzo przekrojowy charakter i stanowi istotny punkt wyjścia do dalszych rozważań zawartych w pracy.

W rozdziale drugim M. Kowalewski odniósł się bezpośrednio do przedmiotu badań, jakim jest zagadnienie miejskiego protestu. Analizie został poddany proces kształtowania się tego zjawiska, począwszy od dyspozycji obywateli jako jednostek, po zorganizowane działania zbiorowości. Autor dokonał analizy społecznej członków protestu, posługując się głównie przykładami krajów europejskich. Celem tej analizy była próba wskazania, które z kategorii społecznych mają największy potencjał emancypacyjny, umożliwiający zmianę społeczną. Ukazane są również przyczyny protestów miejskich, z jednoczesnym podkreśleniem trudności związanej z włączeniem kategorii niezadowolenia nacechowanego negatywnymi emocjami do analiz obywatelskiej podmiotowości.

W pracy został również poruszony temat ruchów społecznych oraz ich podkategorii, jaką stanowią ruchy miejskie jako zorganizowana forma wyrażenia niezadowolenia w mieście. Należy zwrócić uwagę na fakt, że autor bardzo rzetelnie przedstawił zagadnienia ruchów miejskich oraz ich odmian, ukazując niejednoznaczności w definiowaniu i delimitowaniu pojęć. Dokonał krytycznej analizy literatury w tym zakresie i precyzyjnie określił zakres semantyczny pojęć, jakimi posługiwał się $\mathrm{w}$ pracy. Jest to niestety wciąż niewystarczająco często wykorzystywana praktyka, pozwalająca w znaczący sposób niwelować chaos definicyjny, który może wystąpić zwłaszcza w przypadku podejmowania tematyki dotyczącej kształtowania się stosunkowo nowych zjawisk, do których można zaliczyć z pewnością formowanie się ruchów miejskich w Polsce.

Trzeci, najobszerniejszy rozdział koncentruje się na wskazaniu, opisie i klasyfikacji form manifestacji niezadowolenia obywateli miasta $\mathrm{w}$ przestrzeni publicznej, które autor określił jako strategie i taktyki miejskiego protestu. Bardzo istotne jest zwrócenie uwagi na konstytutywną rolę przestrzeni w odniesieniu do zdecydowanej większości taktyk protestu i podkreślenie, że zgodnie z nurtem socjologicznym w badaniach miejskich przestrzeń nie stanowi jedynie ramy określonych zdarzeń, ale jest aktywnym czynnikiem będącym jednocześnie przyczyną zmian i efektem zorganizowania społeczeństwa. Uzupełniając rozważania dotyczące przestrzeni o korelację z działaniami politycznymi przytoczył m.in. słowa E. Wnuka-Lipińskiego wskazujące, że „[i]stnienie przestrzeni publicznej oznacza [...] możliwość uczestniczenia $\mathrm{w}$ relacjach publicznych i w zasadzie wszystkie działania obywatelskie odbywają się w przestrzeni publicznej, ponieważ jedynie tam zyskują swój obywatelski charakter" (Wnuk-Lipiński, 2005, s. 104).

Następnie omówiony został przestrzenny wymiar polityki protestu w kontekście wybranych taktyk i technik. Dokonana została klasyfikacja obszernego katalogu form protestu miejskiego, począwszy od historycznych, zanikających jego postaci, kończąc na nowo powstających współczesnych formach. Za pomocą określonych kryteriów klasyfikacji przeprowadził podział na sześć podstawowych typów form, poczynając od najłagodniejszych form protestu (najmniej interwencyjnych w przestrzeni publicznej) i kończąc na najostrzejszych odmianach protestu. Autor wymienił i opisał: demonstracje uliczne; zakłócenie funkcjonalności systemu miejskiego; interwencje społeczne; strajki, bojkoty i odmowę współpracy; akty symboliczne oraz subwersje, a także formy oparte na przemocy. Typologię tę uzupełniło wskazanie kierunków oddziaływania nowych mediów oraz technologii na zjawisko miejskiego protestu.

M. Kowalewski podjął w swojej książce tematykę, która jest stosunkowo nowa w polskiej literaturze. Temat pracy został przez niego potraktowany interdyscyplinarnie zarówno z dobrą podbudową teoretyczną z zakresu socjologii, jak i nauk o mieście. Uważnie przeanalizował zagadnienie, dokonał precyzyjnego zdefiniowania problemu i rzetelnego badania opartego na dopracowanej metodologii. Miasto stanowiło dla niego obszar analizy zjawisk społecznych, jakimi są zachowania zbiorowe niezadowolonych mieszkańców miast.

Recenzowana praca może być ciekawym źródłem wiedzy dla badaczy z wielu dziedzin. Autor bardzo sprawnie porusza się wokół definicji i teorii oraz ich interpretacji, co powoduje, że książka jest stosunkowo prosta w odbiorze, nawet dla czytelnika nieposiadającego wstępnej wiedzy na poruszane w niej tematy. Warto podkreślić, że ukazał również luki w badaniach, które już znalazły się w analizowanym zakresie zagadnień oraz zwrócił uwagę na problemy badawcze, pozostające wciąż niezbadane. Otwiera to pole dla 
kolejnych badaczy i zdaniem autorki recenzji stanowi bardzo dobrą praktykę sprzyjającą rozwojowi badań, co warte jest docenienia.

\section{PRZYPIS}

1 Analiza, zgodnie ze słowami Apanowicza (2005, s. 28), stanowi „proces myślowy, polegający na rozłożeniu pewnej całości na jej części składowe i rozpatrywanie każdej z nich osobno." Jest tym samym jedynie częścią procesu poznania myślowego. Celu pracy natomiast nie powinien stanowić jedynie proces myślowy, a wynik poznania myślowego i empirycznego, jak np. ustalenie, wyjaśnienie czy opracowanie modelu.

\section{BIBLIOGRAFIA}

Apanowicz, J. (2005). Metodologiczne uwarunkowania pracy naukowej: prace doktorskie, prace habilitacyjne. Warszawa: Difin.

Kowalewski, M. (2016). Protest miejski: przestrzenie, tożsamości i praktyki niezadowolonych obywateli miast. Kraków: Nomos. Wnuk-Lipiński, E. (2005). Socjologia życia publicznego. Warszawa: Scholar.

Patrycja Grzyś Uniwersytet Łódzki Wydziat Nauk Geograficznych Katedra Geografii Regionalnej i Społecznej patrycja.grzys@unilodz.eu 